\title{
Monthly alterations in macromolecular contents of in situ ovules excised from Georgian Pinus taeda $\mathbf{L}$.
}

DENEKE H. MARIAM*, DAVID L. BRAMLETT**, JOHN E. MAYFIELD***, WILlIAM V. DASHEK*

*Department of Biology, Atlanta University, Atlanta, GA 30314, USA

**USDA-SEFES, Dry Branch, GA 31020, USA

*** Department of Biology, North Carolina Central University, Durham, NC 27707, USA

(Received: June 6, 1988. Accepted: June 24, 1988)

\begin{abstract}
Pinus taeda L. (loblolly pine), a commercial timber three of the Southeastern United States, provides a major component of the region's forest resources. We cultured loblolly ovules for in vitro fertilization. This procedure was assisted by quantifying time-dependent alterations of in situ ovular RNA, DNA and total protein (Jan-Aug, 1985) contents for ovules (yr 2 of reproductive cycle). Cold-hot, TCA extracted macromolecules were quantified by colorimetry and UV spectroscopy. Total protein was about $0.4 \mu \mathrm{g}$ per 100 ovules $\times 10^{4}$ (Jan-Apr) and except for July increased to $3.6 \mu \mathrm{g}$ per 100 ovules $\times 10^{4}$ by August. In contrast, RNA "dropped" from 3 to about $1 \mu \mathrm{g}$ per 100 ovules $\times 10^{2}$ (Jan-Mar) and then rose to $7 \mu \mathrm{g}$ per 100 ovules $\times 10^{2}$ by July. The DNA climbed from about 1 to above $8 \mu \mathrm{g}$ per 100 ovules $\times 10^{2}$ (Jan-Mar) and then plummeted to $1 \mu \mathrm{g}$ per 100 ovules $\times 10^{2}$ (Apr-June). The observed alterations may reflect ovule morphogenesis.
\end{abstract}

Key words: in situ, macromolecules, monthly, ovules, Pinus taeda

\section{INTRODUCTION}

Fertilization of the egg cell in loblolly pine does not occur until nearly 15 months after pollination ( $\mathrm{March}$ et al. 1987). As this is a critical process in the reproductive development of the species, this study was initiated to attempt in vitro fertilization of pine ovules.

We have attempted to cytologically define the stages of loblolly pine ovule morphogenesis including the timing (March et al. 1985, 1987) as well as develop methods for maintaining ovules in culture (Zdruikovskaja-Rikhter 1983, Mariam et al. 1987, 1988) with the intent of achieving in vitro 
fertilization. Related to this is that clonal production of plantlets from seed embryos is fairly routine (Mott and Anderson 1981). Thus, a biochemical analysis of monthly alterations in ovular macromolecule contents in relation to the cytological definition may be beneficial in establishing ovule cultures by providing in situ comparative data (Mariam et al. 1987). Here are reported monthly changes in RNA, DNA and total protein for ovules freshly-excised from loblolly pine trees.

\section{MATERIALS AND METHODS}

\section{COLLECTION OF OVULES}

Pinus taeda L. conelets were collected monthly from January, 1985 to August, 1985 from a Georgia Forestry Commission Seed Orchard (Pulaski County, Georgia), Once collected, the conelets were returned to the laboratory where ovules were excised within a sterile transfer hood (Mariam et al. 1987).

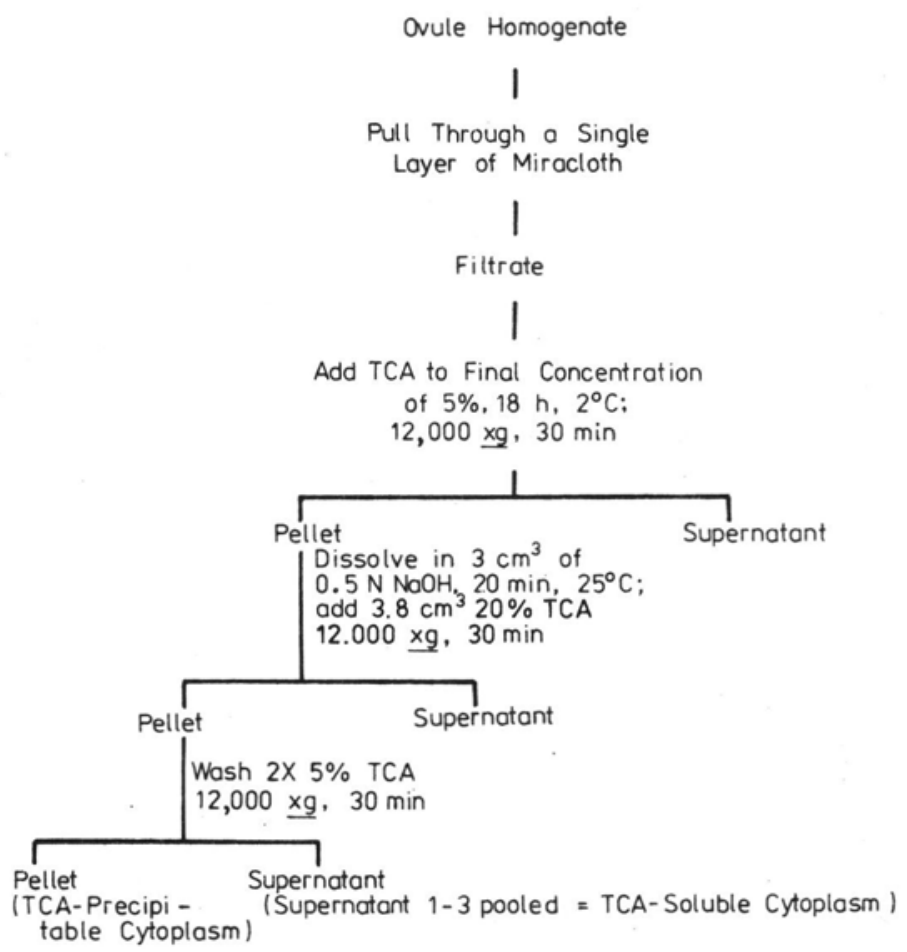

Fig. 1. Flow chart for the preparation of ovular total protein. Adapted from Hollem an and Key (1967) 
Preparation. Freshly-excised ovules were homogenized within a mortar and pestle on ice into a medium consisting of $250 \mathrm{mM}$ sucrose, $3 \mathrm{mM}$ EDTA and $25 \mathrm{mM}$ Tris, pH 7.2 (D anley et al. 1981). The ratio of homogenization buffer to weight of the ovules was $4 \mathrm{~cm}^{3}: 1 \mathrm{~g}$. The homogenate was "pulled through" a single layer of Miracloth (Calbiochem, LaJolla, California). To precipitate both the proteins and nucleic acids within the filtrate, the latter was subjected to trichloroacetic acid (TCA) precipitation procedures (Figs. 1 and 2). Whereas the procedure in Fig. 1 yielded protein, the protocol in Fig. 2 was employed to

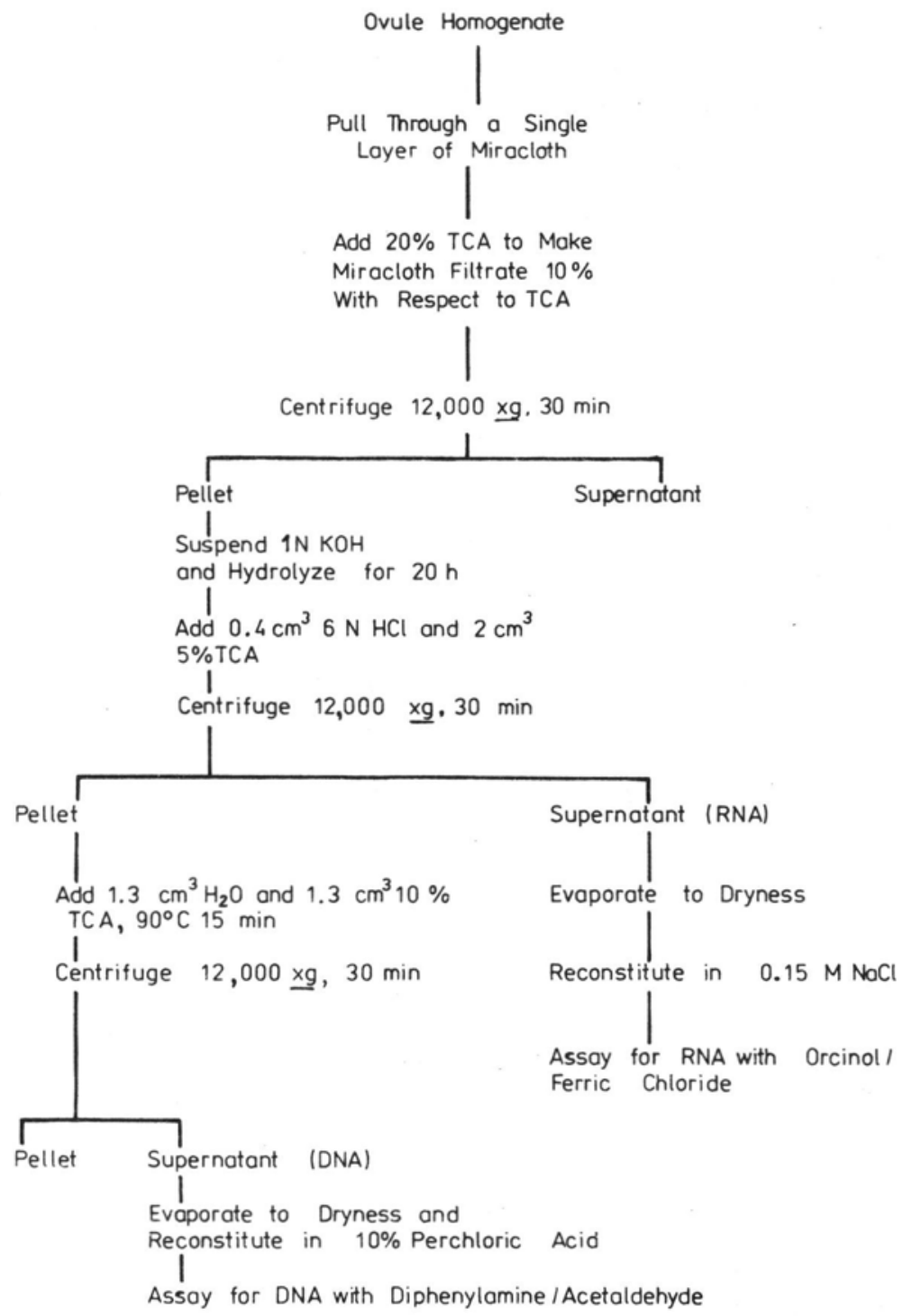

Fig. 2. Flow chart for the preparation of ovular nucleic acids. Adapted from Schneider (1957) 
obtain both RNA and DNA (Schneider 1957, Dashek 1981). To estimate recoveries, known amounts of protein as well as DNA and RNA were processed through these procedures.

Quantification. Ovular proteins resulting from the TCA precipitation procedures were resuspended in $0.15 \mathrm{M} \mathrm{NaCl}$ and quantified by both UV-spctroscopy at $280 \mathrm{~nm}$ and colorimetrically with Coomassie blue at 595 $\mathrm{nm}$ (Bradford 1976). Bovine-serum albumin (Sigma, St. Louis, Missouri) was employed to construct a standard curve.

Whereas ovular RNA was quantified by both UV-spectroscopy at $260 \mathrm{~nm}$ and colorimetrically at $660 \mathrm{~nm}$ with orcinol (Dische 1962), DNA was assayed via both UV-spectroscopy at $260 \mathrm{~nm}$ and spectrophotometrically at both 595 and $700 \mathrm{~nm}$ with diphenylamine and the difference between the two wave-lengths being recorded (Gyles and Myers 1965). Baker's yeast RNA (type XI, Sigma, St. Louis, Missouri) served for standard curve construction. For all assays, comparisons of absorption spectra of both authentic protein and nucleic acid standards as well as ovule samples were performed to rule out possible interference from contaminating substances. When interferring substances were encountered, "clean-up" procedure such as gel permeation chromatography were employed.

\section{RESULTS}

The results of the time-dependent changes in ovular protein, RNA and DNA contents assayed by both UV and visible spectroscopy are presented in Figs. 3, 4 and 5, respectively.

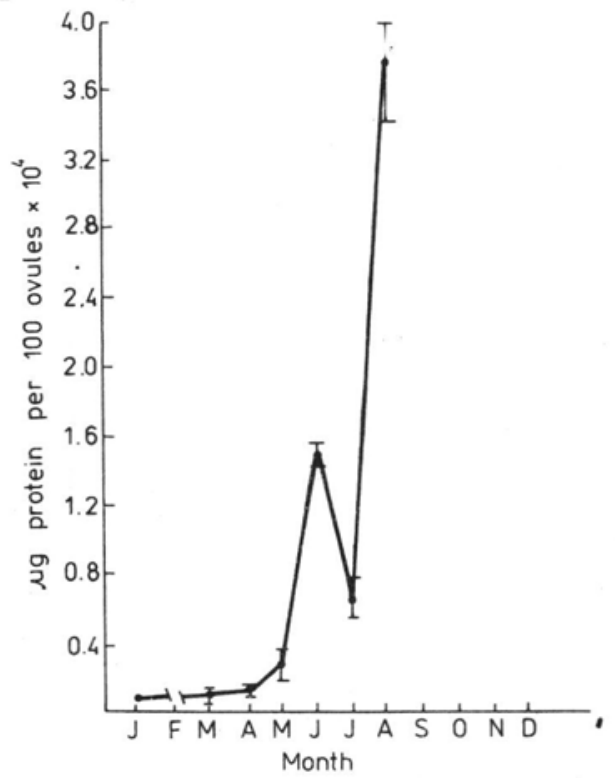

Fig. 3. Ovular total protein as function of month of ovule collection. Data are means and standard deviations where $\mathrm{N}=3$ 


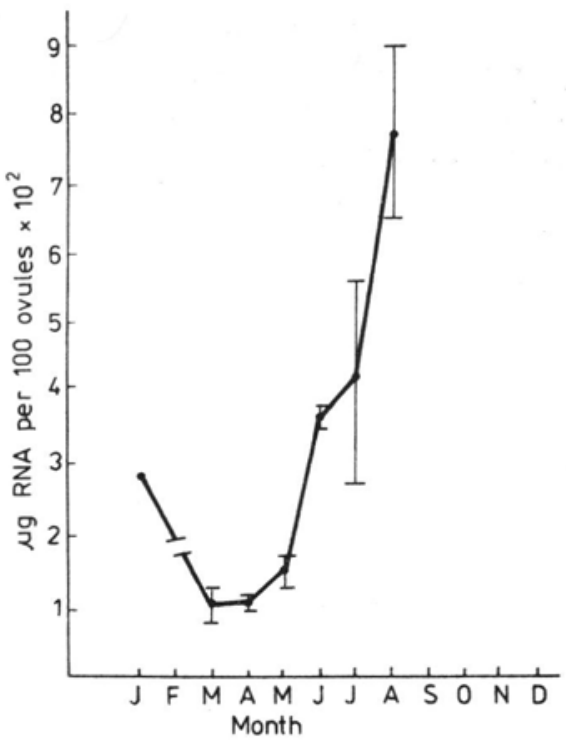

Fig. 4. Monthly alterations in ovular RNA contents. Data are means and standard deviations where $\mathrm{N}=3$

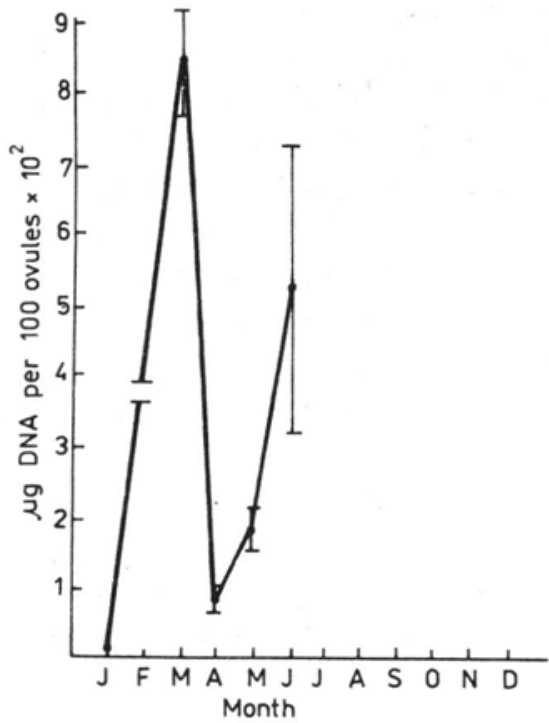

Fig. 5. Monthly changes in ovular DNA contents. Data are means and standard deviations where $\mathrm{N}=3$ 
The macromolecular contents for freshly-excised yr 2 ovules exhibited an increase in protein, RNA and DNA from January, 1985 through August, 1985. Generally, the contents of each macromolecule were low during the winter. The protein content decreased by about $50 \%$ in July ovules as compared to that of June ovules; but it increased almost six-fold in August ovules (Fig. 3). The content of ovular RNA underwent a linear rise from March, 1985 through August, 1985 (Fig. 4). The DNA content of freshly-excised ovules increased by over a hundred-fold from January, 1985 to March, 1985 and then declined in April of that year (Fig. 5). It then rose linearly until June. Due to some interference in the DNA assay mixture, it was not possible to quantify DNA in either July or August ovules.

\section{DISCUSSION}

The elevation in total protein and RNA/DNA during June in freshly-excised ovules may be related to the occurrence of fertilization and the entry of the ovules into rapid metabolic activity (March et al. 1985, 1987). In addition to Pinus taeda, fertilization appears to occur in early-mid June, in other pines, following overwintering of the female gametophyte ( $\mathrm{O}$ we n s et al. 1981). During this time, either new RNA species may be generated or the amount of existing RNA could be increased. These alternatives could possibly be differentiated through quantification of RNA together with the use of ${ }^{15} \mathrm{~N}$ bases and $\mathrm{CsCl}_{2}$ centrifugation of isolated RNAs. To gain insight into which RNA species the isotope was incorporated, chromatography of phenol: $\mathrm{CHCl}_{3}$ :isoamyl alcohol extracted RNA upon oligo-dT cellulose columns (Mascarenhas and Mermelstein 1981) might be useful.

The market rise in DNA content which occurred during March may be related to cell division during the end of the coenocytic stage of ovule development assuming that Pinus taeda's ovule development is similar to that of Pinus sylvestris (Willemse and Franssen-Verheijen 1983). Similarly, the increase in DNA during May may be related to cell division which may occur within the integuments of the ovule cellular stage (Willemse and Franssen-Verheijen 1983). As mentioned, the increase in DNA which occurred in June may be related to fertilization when the ovule could be in the archegonial stage.

As for the time-dependent enhancement in ovular total protein content, it would be of interest to determine if there are proteins unique to enhanced ovular metabolic activities, e.g. esterases, peroxidases and dehydrogenases have been found to vary with the reproductive stages of plant development. This could be examined through the employment of starch gel electrophoresis followed by incubation of the gels with substrates for esterase, peroxidase and dehydrogenase activities. Perhaps, there are enyzmes which underlie the 
change of an ovule from a dormant one to an active one. It is also possible that other enzymes could account for the enhancement in total protein and thus assays for other enyzmes should be employed. The diminution in total protein content from June to July may indicate that cell division does not rapidly occur in July.

\section{Acknowledgements}

We thank Mrs. Ruby Wright for clerical assistance. The results reported herein formed a portion of a thesis submitted by DHM in partial fulfillment of the Degree of Master of Science at Atlanta University, Atlanta, Georgia. The work was supported by USDA-Southeastern Forest Experiment Station research agreement No. 29-145 and its renewal.

\section{REFEREINES}

Bradford M. M., 1976. A rapid and sensitive method for the quantitation of microgram quantities of protein utilizing the principle of protein dye binding. Analyt. Biochem. 72: 248-254.

Danley J. M., Staggers S., Walker S., Varner A., Llewellyn G. C., Dashek W. V., 1981. Aflatoxin-induced alteration in the levels of membrane chemicals of subcellular organelles isolated from excised, incubated Glycine max, cv. "Essex" roots. I. Non-enriched organelles. Mycopathologia 74: 149-161.

Dashek W. V., 1981. Changes in nucleic acid and protein levels during in vitro germination and elongation of Lilium longiflorum, cv. 'Ace' pollen. Acta Soc. Bot. Pol. 50: 39-50.

Dische Z., 1962. Color reactions of carbohydrates. Color reactions of pentoses. Methods Carbohydr. Chem. 1: 414-418.

Gyles K. W., Myers A., 1965. An improved diphenylamine method for the estimation of deoxyribonucleic acid. Nature 206: 93.

Holleman J. M., Key J. L., 1967. Inactive and protein precursor pools of amino acids in the soybean hypocotyl. Plant Physiol. 42: 29-36.

March R. A., Bramlett D. L., Mayfield J. E., Dashek W. V., 1985. Timing of fertilization in Pinus taeda. International Symposium on Pollen Biotechnology and Ecology, Amherst, MA (in press).

March R. A., Bramlett D. L., Mayfield J. E., Dashek W. V., 1987. Seed yields and timing of fertilization of Pinus taeda L. Plant Physiol. 83 (suppl.): 155.

Mariam D. H., Bramlett D. L., Mayfield J. E., Dashek W. V., 1987. Feasibility of culturing excised Pinus taeda L. ovules. Plant Physiol. 83 (suppl.): 155.

Mariam D. H., Bramlett D. L., Mayfield J. E., Dashek W. V., 1988. Developing loblolly pine (Pinus taeda L.) ovule culture to study reproductive development at the cellular level. Amer. J. Bot. (submitted).

Mascarenhas J. P., Mermelstein J., 1981. Messenger RNAs: Their utilization and degradation during pollen germination and tube growth. Acta Soc. Bot. Pol. 50: 13-20.

Mott R. L., Anderson H. V., 1981. A tissue culture process for the clonal production of loblolly pine plantlets. N. C. Agr. Res. Service Tech. Bul. No. 271: 14.

Owens J. H., Simpson S. J., Molder M., 1981. Sexual reproduction of Pinus contorta. II. Postdormancy ovule, embryo, and seed development. Can. J. Bot. 60: 2071-2083. 
Schneider W. C., 1957. Determination of nucleic acids in tissues by pentose analysis. In: Methods in enzymology. S. P. Colowick and N. O. Kaplan (eds.), vol. III. Academic Press, New York, pp. 680-684.

Willemse M. T. M., Franssen-Verheijen M. A. W., 1983. Ovule development. In: Fertilization and embryogenesis in ovulated plants. O. Erdelska, N. Ciamporova, A. Lux, A. Pretova and J. Tupy (eds.). Bratislava, pp. 171-182.

Zdruikovskaja-Rikhter A. J., 1983. In vitro culture of excised embryos and ovules of Cerasus avium (L.) Moench. In: Fertilization and embryogenesis in ovulated plants. O. Erdelska, M. Ciamporova, A. Lux, A. Pretova and J. Tupy (eds.) Bratislava, pp. 311-313.

\section{Zmiany miesięczne skladu makromolekul, badane in situ, zalą̇ków otrzymanych $z$ Pinus taeda L.}

\section{Streszczenie}

Pinus taeda, drzewo z którego drewno jest powszechnie używane jako budulec w południowo-wschodnich stanach USA, stanowi główny składnik zasobów leśnych tych regionów. Hodowaliśmy zalążki Pinus taeda $\mathrm{w}$ celu zapłodnienia in vitro. Ta procedura była pomocna przy określaniu ilościowym zmiennych w czasie wahan zawartości RNA, DNA i białka całkowitego zalążków in situ (styczeń-sierpień 1985) (2-letni cykl rozrodczy). Związki te ekstrahowano kwasem trójchlorooctowym i oznaczano kolorymetrycznie i metodą spektroskopii w UV. Ilość białka całkowitego wyniosła około $0,4 \mu \mathrm{g}$ na 100 zalążków $\times 10^{4}$ (styczeń-kwiecień) i, z wyjątkiem lipca, wzrosła do 3,6 $\mu \mathrm{g}$ na 100 zalążzów $\times 10^{4}$ w sierpniu. Natomiast RNA "spad»" z 3 do około $1 \mu \mathrm{g}$ na 100 zalążków $\times 10^{2}$ (styczeń-marzec) i następnie jego poziom wzrósł do $7 \mu \mathrm{g}$ na 100 zalążków $\times 10^{2}$ w lipcu. Zawartość DNA wzrosła $\mathrm{z}$ około 1 do ponad $8 \mu \mathrm{g}$ na 100 zalążków $\times 10^{2}$ (styczeń-marzec) i następnie zmniejszyła się do $1 \mu \mathrm{g}$ na 100 zalążków $\times 10^{2}$ (kwiecień-czerwiec). Obserwowane wahania badanych makromolekuł mogą być wynikiem morfogenezy zalążków. 